(2) Open Access Full Text Article

REVIEW

\title{
Overview of saxagliptin efficacy and safety in patients with type 2 diabetes and cardiovascular disease or risk factors for cardiovascular disease
}

This article was published in the following Dove Press journal:

Vascular Health and Risk Management

23 December 2014

Number of times this article has been viewed

\section{Peter P Toth ${ }^{1,2}$}

'CGH Medical Center, Sterling IL, USA, ${ }^{2}$ Johns Hopkins University School of Medicine, Baltimore, MD, USA
Correspondence: Peter P Toth CGH Medical Center, I0I East Miller Road, Sterling, IL, USA 6108I

$\mathrm{Tel}+\mathrm{I} 8156325093$

Fax + I 8156265947

Email peter.toth@cghmc.com
Abstract: Most individuals with type 2 diabetes mellitus have or will develop multiple independent risk factors for cardiovascular disease, particularly coronary artery disease (CAD). CAD is the leading cause of morbidity and mortality among individuals with type 2 diabetes mellitus, and treating these patients is challenging. The risk of hypoglycemia, weight gain, or fluid retention with some diabetes medications should be considered when developing a treatment plan for individuals with a history of CAD or at risk for CAD. Dipeptidyl peptidase-4 inhibitors are oral antihyperglycemic agents that inhibit the breakdown of the incretin hormones glucagon-like peptide-1 and glucose-dependent insulinotropic polypeptide, resulting in increased glucose-dependent insulin secretion and suppression of glucagon secretion. Saxagliptin is a potent and selective dipeptidyl peptidase-4 inhibitor that improves glycemic control and is generally well tolerated when used as monotherapy and as add-on therapy to other antihyperglycemic medications. This review summarizes findings from recently published post hoc analyses of saxagliptin clinical trials that have been conducted in patients with and without a history of cardiovascular disease and in patients with and without various risk factors for cardiovascular disease. The results show that saxagliptin was generally well tolerated and consistently improved glycemic control, as assessed by reductions from baseline in glycated hemoglobin, fasting plasma glucose concentration, and postprandial glucose concentration, regardless of the presence or absence of baseline cardiovascular disease, hypertension, statin use, number of cardiovascular risk factors, or high Framingham 10-year cardiovascular risk score.

Keywords: cardiovascular disease, dipeptidyl peptidase-4 inhibitors, incretin, saxagliptin, type 2 diabetes mellitus

\section{Introduction}

Diagnosed and undiagnosed diabetes, primarily type 2 diabetes mellitus (T2DM), affects an estimated $9.3 \%$ of the US population, and $25.9 \%$ of these are aged $\geq 65$ years. ${ }^{1}$ Most individuals with T2DM have or will develop multiple independent risk factors for cardiovascular disease (CVD), including hypertension, dyslipidemia, obesity, chronic kidney disease, and microalbuminuria. ${ }^{1-4}$ Therefore, it is not surprising that CVD, in particular coronary artery disease (CAD), is the leading cause of morbidity and mortality among individuals with T2DM. ${ }^{5}$ Adults with T2DM have a 2-fold to 5-fold higher risk of CVD compared with those without T2DM, ${ }^{6,7}$ and $68 \%$ of deaths in individuals with T2DM aged $\geq 65$ years are the result of CVD. ${ }^{8}$

Although observational studies suggest that hyperglycemia is associated with adverse cardiovascular events, ${ }^{9-11}$ there is little evidence from interventional studies 
that reducing hyperglycemia reduces the number of adverse cardiovascular outcomes. ${ }^{12-14}$ However, a long-term follow-up of the United Kingdom Prospective Diabetes Study ${ }^{15}$ and a meta-analysis of five major diabetes trials ${ }^{16}$ showed that, in individuals with T2DM, intensive glycemic control compared with dietary or standard care reduced mortality and some adverse cardiovascular outcomes, such as myocardial infarction (MI) and CAD. Moreover, intensive glycemic control, aggressive management of risk factors for CVD (eg, with antihypertensives, lipid-lowering agents, and aspirin therapy), and behavior modification have been shown to reduce the risk of adverse cardiovascular events and mortality in patients with T2DM and microalbuminuria. ${ }^{17,18}$

Treating patients with T2DM and a history of or risk factors for CVD is challenging because they are usually receiving several medications to treat multiple comorbidities, may be elderly, may be part of patient populations for whom various drugs are contraindicated (eg, nephropathy, congestive heart failure), and may have decreased medication adherence. ${ }^{19,20}$ Moreover, the risk of hypoglycemia, weight gain, or fluid retention with some diabetes medications, such as sulfonylureas and thiazolidinediones, should be considered when developing a treatment plan for individuals with a history of or risk factors for CVD. ${ }^{21,22}$
The incretin hormones glucagon-like peptide-1 (GLP-1) and glucose-dependent insulinotropic polypeptide are released by the gut in response to ingestion of food and have a number of actions on multiple organs (Figure 1). ${ }^{23}$ Both hormones increase glucose-dependent insulin secretion. GLP-1 also suppresses glucagon secretion, inhibits gastric emptying, and induces satiety. Dipeptidyl peptidase-4 (DPP-4) is a ubiquitous enzyme that is responsible for the proteolytic inactivation of GLP-1 and glucose-dependent insulinotropic polypeptide. DPP-4 inhibitors are oral antihyperglycemic agents that inhibit the breakdown of GLP-1 and glucose-dependent insulinotropic polypeptide, and thus augment plasma levels of these hormones. ${ }^{23}$ Saxagliptin is a potent and selective DPP-4 inhibitor that improves glycemic control and is generally well tolerated when used as monotherapy ${ }^{24,25}$ and as add-on therapy to metformin, ${ }^{26}$ glyburide, ${ }^{27}$ pioglitazone, ${ }^{28}$ or insulin \pm metformin. ${ }^{29}$ In contrast with insulin, sulfonylureas, and thiazolidinediones, DPP-4 inhibitors are weight neutral and are associated with a low rate of hypoglycemia when used as monotherapy. ${ }^{30,31}$ In recent years, multiple post hoc analyses of saxagliptin clinical trials have been conducted to examine the efficacy and safety of saxagliptin in subgroups of patients with and without a history of CVD, with and without various cardiovascular risk factors, and with and without concomitant

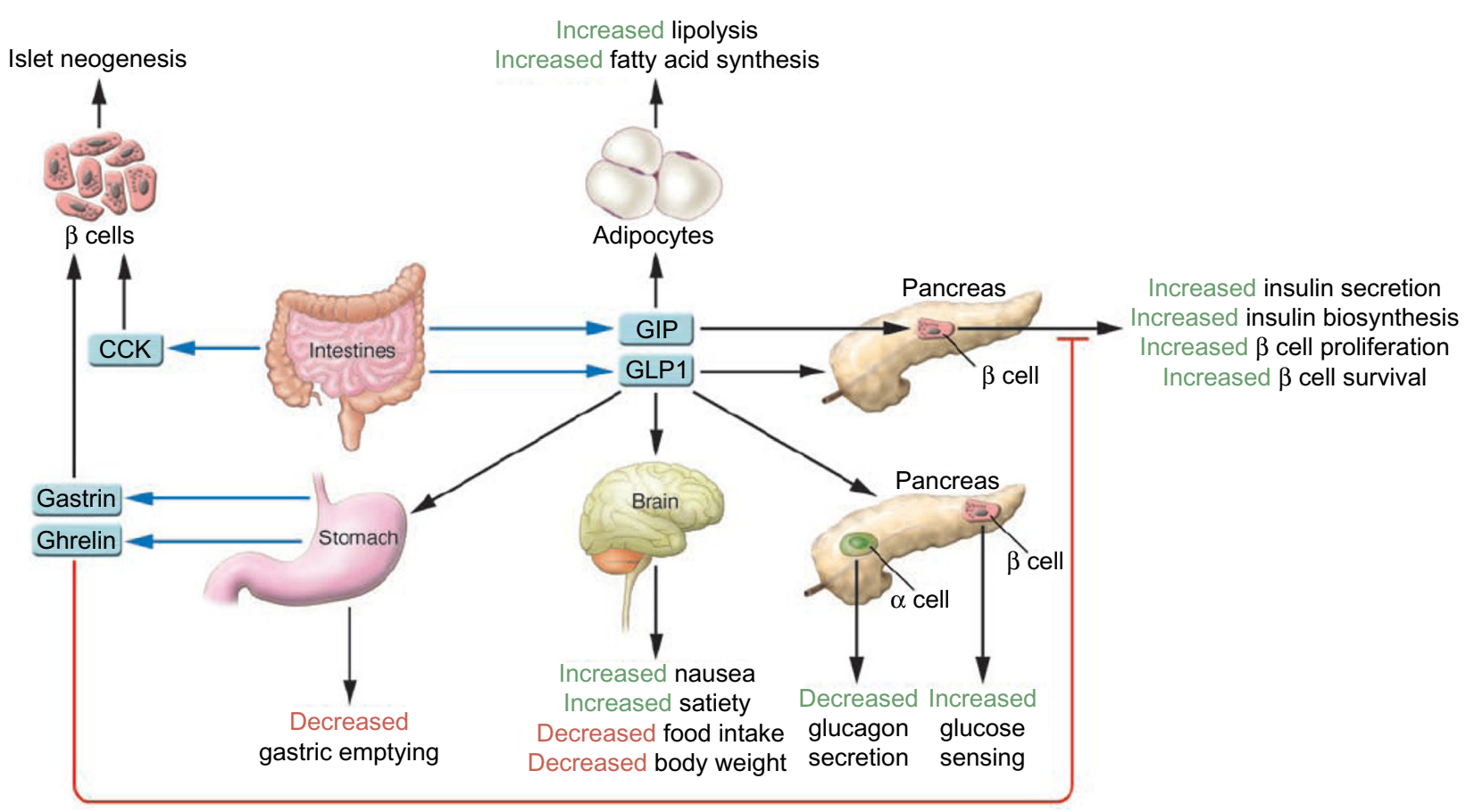

Figure I Role of incretin hormones in glucose regulation.

Note: Reproduced with permission from Drucker DJ. The role of gut hormones in glucose homeostasis. J Clin Invest. 2007; I I7:24-32.23

Abbreviations: CCK, cholecystokinin; GIP, glucose-dependent insulinotropic polypeptide; GLP-I, glucagon-like peptide-I. 
statin therapy. The purpose of this review is to summarize the findings from these analyses.

\section{Efficacy and safety of saxagliptin in patients with a history of or risk factors for CVD}

Analyses of the efficacy and safety of saxagliptin in patients with a history of or risk factors for CVD (eg, hypertension, dyslipidemia, smoking, or a family history of CVD) were performed in two groups of patients. In the first analysis, data from five randomized, placebo- controlled, 24-week, Phase III clinical trials were pooled and compared saxagliptin $5 \mathrm{mg}$ /day with placebo. ${ }^{32}$ The five-study pool (Table 1) consisted of two studies of saxagliptin as monotherapy in drug-naïve patients ${ }^{24,25}$ and one study each of saxagliptin as add-on therapy to metformin, ${ }^{26}$ glyburide, ${ }^{27}$ or pioglitazone. ${ }^{28}$ In the second analysis, three randomized, controlled Phase III clinical trials were compared side by side. ${ }^{33}$ These studies were of saxagliptin $5 \mathrm{mg}$ /day in combination with metformin as initial therapy in treatment-naïve patients for 24 weeks, ${ }^{34}$ saxagliptin add-on to metformin versus glipizide add-on

Table I Saxagliptin clinical trials

\begin{tabular}{|c|c|c|c|c|}
\hline Study & $\mathbf{N}^{*}$ & Treatment & $\begin{array}{l}\text { Mean baseline } \\
\mathrm{HbA}_{\mathrm{Ic}}, \%^{\dagger}\end{array}$ & $\begin{array}{l}\text { Mean duration } \\
\text { of T2DM, years }\end{array}$ \\
\hline \multicolumn{5}{|l|}{ Five-study pool } \\
\hline NCT00I2164I25 & 401 & SAXA $2.5,5$, or $10 \mathrm{mg} /$ day versus $\mathrm{PBO}$ & $7.8-8.0$ & $2.3-3.1$ \\
\hline NCT00316082 24 & 365 & $\begin{array}{l}\text { SAXA } 2.5 \mathrm{mg} \text { QAM } \pm \text { titration to } 5 \mathrm{mg}, 5 \mathrm{mg} \text { QAM, or } \\
5 \mathrm{mg} \text { QPM versus PBO }\end{array}$ & $7.8-8.0$ & $1.2-2.0$ \\
\hline NCT00I $21667^{26}$ & 743 & SAXA $2.5,5$, or 10 mg/day + MET versus PBO + MET & 8.0 & 6.5 \\
\hline NCT003। $3313^{27}$ & 768 & SAXA 2.5 or $5 \mathrm{mg} /$ day + GLY versus PBO + uptitrated GLY & $8.4-8.5$ & $6.8-7.1$ \\
\hline NCT0029563328 & 565 & SAXA 2.5 or 5 mg/day + TZD versus PBO + TZD & $8.2-8.4$ & $5.1-5.3$ \\
\hline \multicolumn{5}{|l|}{ Three side-by-side } \\
\hline \multirow[t]{2}{*}{ NCT003270I5 $\$ 34$} & 1,306 & SAXA 5 or $10 \mathrm{mg} /$ day + MET versus SAXA & $9.4-9.6$ & 1.4-2.0 \\
\hline & & $10 \mathrm{mg} /$ day $+\mathrm{PBO}$ or $\mathrm{MET}+\mathrm{PBO}$ & & \\
\hline NCT00575588 35 & 858 & SAXA 5 mg/day + MET versus glipizide + MET & 7.7 & $5.4-5.5$ \\
\hline NCT0075758829 & 455 & SAXA $5 \mathrm{mg} /$ day + INS \pm MET versus $\mathrm{PBO}+\mathrm{INS} \pm \mathrm{MET}$ & $8.6-8.7$ & $11.8-12.2$ \\
\hline \multicolumn{5}{|l|}{ Nine-study pool } \\
\hline NCT00I $\left.2164\right|^{25}$ & 401 & SAXA $2.5,5$, or $10 \mathrm{mg} /$ day versus $\mathrm{PBO}$ & $7.8-8.0$ & $2.3-3.1$ \\
\hline NCT003I6082 24 & 365 & $\begin{array}{l}\text { SAXA } 2.5 \mathrm{mg} \text { QAM } \pm \text { titration to } 5 \mathrm{mg}, 5 \mathrm{mg} \text { QAM, or } \\
5 \mathrm{mg} \text { QPM versus PBO }\end{array}$ & $7.8-8.0$ & $1.2-2.0$ \\
\hline NCT00698932 $2^{42}$ & 568 & SAXA $5 \mathrm{mg} /$ day versus $\mathrm{PBO}$ & $8.1-8.2$ & $0.8-1.2$ \\
\hline NCT0091887943 & 213 & $\mathrm{SAXA} 5 \mathrm{mg} /$ day versus $\mathrm{PBO}$ & 8.3 & 0.9 \\
\hline NCT00I $21667^{26}$ & 743 & $\mathrm{SAXA} 2.5,5$, or $10 \mathrm{mg} /$ day $+\mathrm{MET}$ versus $\mathrm{PBO}+\mathrm{MET}$ & 8.0 & 6.5 \\
\hline NCT00661362 44 & 570 & SAXA 5 mg/day + MET versus PBO + MET & 7.9 & 5.1 \\
\hline NCT003। $3313^{27}$ & 768 & SAXA 2.5 or $5 \mathrm{mg} /$ day + GLY versus PBO + uptitrated GLY & $8.4-8.5$ & $6.8-7.1$ \\
\hline NCT0029563328 & 565 & SAXA 2.5 or 5 mg/day + TZD versus PBO + TZD & $8.2-8.4$ & $5.1-5.3$ \\
\hline NCT0075758829 & 455 & SAXA $5 \mathrm{mg} /$ day + INS \pm MET versus $\mathrm{PBO}+\mathrm{INS} \pm \mathrm{MET}$ & $8.6-8.7$ & $11.8-12.2$ \\
\hline \multicolumn{5}{|c|}{ Additional studies in eleven-study safety pool } \\
\hline NCT0I00659045 & 286 & SAXA 5 mg/day + MET versus MET uptitration & 7.7-7.8 & $6.0-6.9$ \\
\hline \multirow[t]{2}{*}{ NCT003270I5 $\$ 34$} & 1,306 & SAXA 5 or $10 \mathrm{mg} /$ day + MET versus SAXA & $9.4-9.6$ & $1.4-2.0$ \\
\hline & & $10 \mathrm{mg} /$ day $+\mathrm{PBO}$ or $\mathrm{MET}+\mathrm{PBO}$ & & \\
\hline \multicolumn{5}{|c|}{ Additional studies in the 20 -study safety pool } \\
\hline NCT006/493946 & 170 & SAXA $2.5 \mathrm{mg} /$ day versus PBO ( \pm other OADs or INS) & $8.1-8.5$ & $15.1-18.2$ \\
\hline NCT0095059948 & 338 & SAXA $2.5,5,10,20,40$, or $100 \mathrm{mg} /$ day versus $\mathrm{PBO}$ & $7.5-8.0$ & $0.3-1.8$ \\
\hline NCT0037490749 & 36 & SAXA $5 \mathrm{mg} /$ day versus PBO & $6.6-6.9$ & $2.7-3.7$ \\
\hline NCT00575588 35 & 858 & SAXA 5 mg/day + MET versus glipizide + MET & 7.7 & $5.4-5.5$ \\
\hline NCT00666458 50 & 801 & SAXA $5 \mathrm{mg} /$ day + MET versus SITA $100 \mathrm{mg} /$ day + MET & 7.7 & 6.3 \\
\hline NCT00683657 & 93 & SAXA 5 mg/day + MET XR versus PBO + MET XR & 8.1 & 6.9 \\
\hline NCT00885378 52 & 160 & SAXA (2.5 mg twice daily) + MET versus PBO + MET & 7.9-8.0 & $5.8-6.2$ \\
\hline NCT0091813853 & 93 & SAXA $5 \mathrm{mg} /$ day + MET XR versus MET XR uptitration & $8.4-8.6$ & $5.1-6.2$ \\
\hline NCT00960076 54 & 282 & SAXA $5 \mathrm{mg} /$ day + MET XR versus MET XR uptitration & $8.3-8.4$ & $5.9-6.5$ \\
\hline
\end{tabular}

Notes: *Randomized and treated patients. †Range of values where indicated. ${ }^{\ddagger}$ Only the saxagliptin + metformin and metformin + placebo arms were included in the analyses. Abbreviations: GLY, glyburide; $\mathrm{HbA}_{1 \mathrm{c}}$, glycated hemoglobin; INS, insulin; MET, metformin; OAD, oral antihyperglycemic drug; PBO, placebo; QAM, once daily AM; QPM, once daily PM; SAXA, saxagliptin; SITA, sitagliptin; T2DM, type 2 diabetes mellitus; TZD, thiazolidinedione; XR, extended release. 


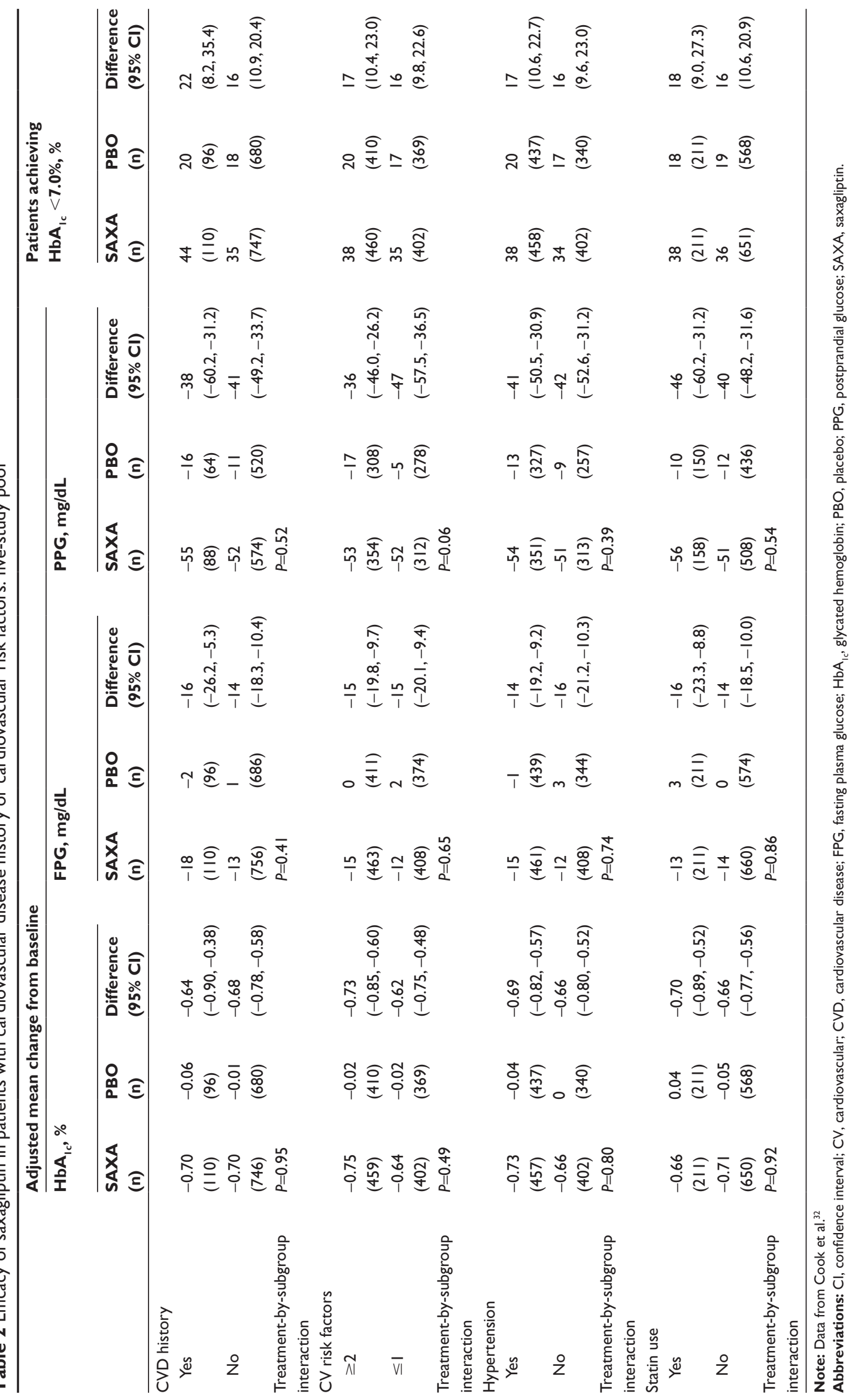


to metformin for 52 weeks, ${ }^{35}$ and saxagliptin add-on to insulin \pm metformin versus placebo add-on to insulin \pm metformin for 24 weeks $^{29}$ (Table 1).

In all studies analyzed, patients were aged 18-77 years with T2DM and had a glycated hemoglobin $\left(\mathrm{HbA}_{1 \mathrm{c}}\right)$ level of $7 \%-10 \%,{ }^{24-26} 7.5 \%-10 \%,{ }^{27} 7 \%-10.5 \%,{ }^{28} 8 \%-12 \%,{ }^{34}>6.5 \%$ $10 \%,{ }^{35}$ or $7.5 \%-11 \%{ }^{29}$ Major exclusion criteria that were common to all studies included: symptoms of poorly controlled diabetes; a significant cardiovascular event within 6 months of study entry or New York Heart Association class III or IV congestive heart failure and/or left ventricular ejection fraction $\leq 40 \%$; and a significant history of renal or hepatic disease.

Efficacy end points were adjusted mean change from baseline to study end in $\mathrm{HbA}_{1 \mathrm{c}}$, 120-minute postprandial glucose (PPG) concentration, fasting plasma glucose (FPG) concentration, and the proportion of patients achieving a therapeutic target of $\mathrm{HbA}_{1 \mathrm{c}}<7 \%$ at the end of the study. Safety data were analyzed for adverse events and all reported and confirmed hypoglycemia (fingerstick blood glucose level $\leq 50 \mathrm{mg} / \mathrm{dL}$ with associated symptoms). Efficacy was compared between patients with and without a history of CVD, patients with two or more cardiovascular risk factors and with no more than one cardiovascular risk factor, patients with and without hypertension, and patients with and without statin use. In all studies reported in this overview, treatment-by-subgroup interactions were analyzed to detect the inconsistency of treatment effects between saxagliptin and control across subgroups. Analyses that resulted in $P<0.1$ were considered to be suggestive of differential treatment effects among subgroups without judgment as to the statistical significance of the findings.

Table 3 Change in $\mathrm{HbA}_{\mathrm{lc}}$ with saxagliptin in patients with cardiovascular disease history or cardiovascular risk factors: three side-byside studies

\begin{tabular}{|c|c|c|c|c|c|c|c|c|c|}
\hline & \multicolumn{9}{|c|}{ Adjusted mean change from baseline in $\mathrm{HbA}_{\mathrm{lc}}$} \\
\hline & $\begin{array}{l}\text { SAXA + } \\
\text { MET } \\
\text { (n) }\end{array}$ & $\begin{array}{l}\text { PBO + } \\
\text { MET } \\
\text { (n) }\end{array}$ & $\begin{array}{l}\text { Difference } \\
(95 \% \mathrm{Cl})\end{array}$ & $\begin{array}{l}\text { SAXA + } \\
\text { MET } \\
\text { (n) }\end{array}$ & $\begin{array}{l}\text { GLIP + } \\
\text { MET } \\
\text { (n) }\end{array}$ & $\begin{array}{l}\text { Difference } \\
(95 \% \mathrm{Cl})\end{array}$ & $\begin{array}{l}\text { SAXA + } \\
\text { INS } \pm \text { MET } \\
\text { (n) }\end{array}$ & $\begin{array}{l}\text { PBO + } \\
\text { INS } \pm \\
\text { MET } \\
\text { (n) }\end{array}$ & $\begin{array}{l}\text { Difference } \\
(95 \% \mathrm{Cl})\end{array}$ \\
\hline \multicolumn{10}{|l|}{ CVD history } \\
\hline Yes & $\begin{array}{l}-2.14 \\
(32)\end{array}$ & $\begin{array}{l}-1.76 \\
(52)\end{array}$ & $\begin{array}{l}-0.38 \\
(-0.91,0.15)\end{array}$ & $\begin{array}{l}-0.49 \\
(76)\end{array}$ & $\begin{array}{l}-0.70 \\
(89)\end{array}$ & $\begin{array}{l}0.21 \\
(-0.04,0.46)\end{array}$ & $\begin{array}{l}-0.73 \\
(84)\end{array}$ & $\begin{array}{l}-0.50 \\
(39)\end{array}$ & $\begin{array}{l}-0.23 \\
(-0.57,0.10)\end{array}$ \\
\hline No & $\begin{array}{l}-2.53 \\
(274)\end{array}$ & $\begin{array}{l}-1.97 \\
(261)\end{array}$ & $\begin{array}{l}-0.56 \\
(-0.77,-0.36)\end{array}$ & $\begin{array}{l}-0.58 \\
(347)\end{array}$ & $\begin{array}{l}-0.64 \\
(334)\end{array}$ & $\begin{array}{l}0.06 \\
(-0.06,0.18)\end{array}$ & $\begin{array}{l}-0.73 \\
(216)\end{array}$ & $\begin{array}{l}-0.25 \\
(110)\end{array}$ & $\begin{array}{l}-0.48 \\
(-0.68,-0.27)\end{array}$ \\
\hline $\begin{array}{l}\text { Treatment-by-subgroup } \\
\text { interaction } \\
\text { CV risk factors }\end{array}$ & $P=0.53$ & & & $P=0.28$ & & & $P=0.22$ & & \\
\hline$\geq 2$ & $\begin{array}{l}-2.54 \\
(124)\end{array}$ & $\begin{array}{l}-2.16 \\
(124)\end{array}$ & $\begin{array}{l}-0.38 \\
(-0.68,-0.08)\end{array}$ & $\begin{array}{l}-0.56 \\
(259)\end{array}$ & $\begin{array}{l}-0.64 \\
(273)\end{array}$ & $\begin{array}{l}0.08 \\
(-0.06,0.22)\end{array}$ & $\begin{array}{l}-0.70 \\
(145)\end{array}$ & $\begin{array}{l}-0.43 \\
(80)\end{array}$ & $\begin{array}{l}-0.26 \\
(-0.50,-0.02)\end{array}$ \\
\hline$\leq 1$ & $\begin{array}{l}-2.45 \\
(182)\end{array}$ & $\begin{array}{l}-1.78 \\
(189)\end{array}$ & $\begin{array}{l}-0.67 \\
(-0.91,-0.42)\end{array}$ & $\begin{array}{l}-0.58 \\
(164)\end{array}$ & $\begin{array}{l}-0.68 \\
(150)\end{array}$ & $\begin{array}{l}0.10 \\
(-0.08,0.28)\end{array}$ & $\begin{array}{l}-0.76 \\
(155)\end{array}$ & $\begin{array}{l}-0.18 \\
(69)\end{array}$ & $\begin{array}{l}-0.58 \\
(-0.83,-0.33)\end{array}$ \\
\hline $\begin{array}{l}\text { Treatment-by-subgroup } \\
\text { interaction } \\
\text { Hypertension }\end{array}$ & $P=0.15$ & & & $P=0.84$ & & & $P=0.07$ & & \\
\hline Yes & $\begin{array}{l}-2.50 \\
(154)\end{array}$ & $\begin{array}{l}-2.02 \\
(167)\end{array}$ & $\begin{array}{l}-0.47 \\
(-0.74,-0.21)\end{array}$ & $\begin{array}{l}-0.58 \\
(313)\end{array}$ & $\begin{array}{l}-0.69 \\
(305)\end{array}$ & $\begin{array}{l}0.11 \\
(-0.02,0.24)\end{array}$ & $\begin{array}{l}-0.75 \\
(232)\end{array}$ & $\begin{array}{l}-0.33 \\
(I \mid 2)\end{array}$ & $\begin{array}{l}-0.4 \mathrm{I} \\
(-0.6 \mathrm{I},-0.2 \mathrm{I})\end{array}$ \\
\hline No & $\begin{array}{l}-2.48 \\
(152)\end{array}$ & $\begin{array}{l}-1.82 \\
(145)\end{array}$ & $\begin{array}{l}-0.66 \\
(-0.93,-0.38)\end{array}$ & $\begin{array}{l}-0.52 \\
(109)\end{array}$ & $\begin{array}{l}-0.56 \\
(118)\end{array}$ & $\begin{array}{l}0.03 \\
(-0.18,0.25)\end{array}$ & $\begin{array}{l}-0.65 \\
(66)\end{array}$ & $\begin{array}{l}-0.27 \\
(36)\end{array}$ & $\begin{array}{l}-0.38 \\
(-0.75,-0.02)\end{array}$ \\
\hline $\begin{array}{l}\text { Treatment-by-subgroup } \\
\text { interaction } \\
\text { Statin use }\end{array}$ & $P=0.34$ & & & $P=0.54$ & & & $P=0.89$ & & \\
\hline Yes & $\begin{array}{l}-2.40 \\
(19)\end{array}$ & $\begin{array}{l}-1.84 \\
(27)\end{array}$ & $\begin{array}{l}-0.56 \\
(-1.28,0.15)\end{array}$ & $\begin{array}{l}-0.50 \\
(177)\end{array}$ & $\begin{array}{l}-0.63 \\
(169)\end{array}$ & $\begin{array}{l}0.13 \\
(-0.04,0.30)\end{array}$ & $\begin{array}{l}-0.82 \\
(102)\end{array}$ & $\begin{array}{l}-0.40 \\
(7 I)\end{array}$ & $\begin{array}{l}-0.42 \\
(-0.69,-0.15)\end{array}$ \\
\hline No & $\begin{array}{l}-2.49 \\
(287)\end{array}$ & $\begin{array}{l}-1.94 \\
(286)\end{array}$ & $\begin{array}{l}-0.55 \\
(-0.75,-0.36)\end{array}$ & $\begin{array}{l}-0.61 \\
(246)\end{array}$ & $\begin{array}{l}-0.67 \\
(254)\end{array}$ & $\begin{array}{l}0.06 \\
(-0.08,0.20)\end{array}$ & $\begin{array}{l}-0.69 \\
(198)\end{array}$ & $\begin{array}{l}-0.25 \\
(78)\end{array}$ & $\begin{array}{l}-0.44 \\
(-0.67,-0.21)\end{array}$ \\
\hline $\begin{array}{l}\text { Treatment-by-subgroup } \\
\text { interaction }\end{array}$ & $P=0.98$ & & & $P=0.56$ & & & $P=0.93$ & & \\
\hline
\end{tabular}

Note: Data from Minervini et $\mathrm{al}^{33}$ and Cook et al. $^{36}$

Abbreviations: $\mathrm{Cl}$, confidence interval; CV, cardiovascular; CVD, cardiovascular disease; GLIP, glipizide; HbA PBO, placebo; SAXA, saxagliptin. 


\section{Efficacy}

In the five-study pooled analysis, greater reductions from baseline in $\mathrm{HbA}_{1 \mathrm{c}}$, FPG, and PPG were observed with saxagliptin compared with placebo in patients with or without a history of CVD, in patients with two or more cardiovascular risk factors or with no more than one cardiovascular risk factor, in patients with or without hypertension, and in patients with or without statin use (Table 2). ${ }^{32}$ There was no evidence of a treatment-by-subgroup interaction for $\mathrm{HbA}_{1 \mathrm{c}}$ or FPG, indicating that there was no difference in the treatment effect of saxagliptin on these parameters based on the presence or absence of CVD history, cardiovascular risk factors, hypertension, or statin use. However, there was a strong trend toward an interaction $(P=0.06)$ for PPG and the number of cardiovascular risk factors. This appears to be the result of a numerically greater reduction from baseline in placebo-treated patients with two or more cardiovascular risk factors compared with those with no more than one cardiovascular risk factor. PPG reductions from baseline in the saxagliptin-treated patients did not differ between subgroups. At week 24, the proportion of patients achieving $\mathrm{HbA}_{1 \mathrm{c}}<7 \%$ was higher with saxagliptin compared with placebo regardless of subgroup. ${ }^{32}$

In the three-study side-by-side analyses of changes from baseline in $\mathrm{HbA}_{1 \mathrm{c}}$ (Table 3), saxagliptin reduced $\mathrm{HbA}_{1 \mathrm{c}}$ to a greater extent than placebo in the add-on to metformin and add-on to insulin studies, whereas similar decreases in $\mathrm{HbA}_{1 \mathrm{c}}$ were seen with saxagliptin compared with glipizide. ${ }^{33,36}$ There was a suggestion of a treatment-by-subgroup interaction in the cardiovascular risk factor analysis in the add-on

Table 4 Change in fasting plasma glucose with saxagliptin in patients with cardiovascular disease history or cardiovascular risk factors: three side-by-side studies

\begin{tabular}{lllllllll}
\multicolumn{7}{l}{ Adjusted mean change from baseline in FPG, $\mathrm{mg} / \mathrm{dL}$} \\
\hline SAXA + & PBO + & Difference & SAXA + & GLIP + & Difference & SAXA + & PBO + & Difference \\
MET & MET & $(95 \% \mathrm{Cl})$ & MET & MET & $(95 \% \mathrm{Cl})$ & INS \pm MET & INS \pm & $(95 \% \mathrm{Cl})$ \\
$(\mathrm{n})$ & $(\mathrm{n})$ & & (n) & $(\mathrm{n})$ & & (n) & MET &
\end{tabular}

\begin{tabular}{|c|c|c|c|c|c|c|c|c|c|}
\hline \multicolumn{10}{|c|}{ (n) } \\
\hline \multicolumn{10}{|l|}{ CVD history } \\
\hline Yes & $\begin{array}{l}-47 \\
(34)\end{array}$ & $\begin{array}{l}-45 \\
(52)\end{array}$ & $\begin{array}{l}-2 \\
(-19.9,15.7)\end{array}$ & $\begin{array}{l}-7 \\
(74)\end{array}$ & $\begin{array}{l}-19 \\
(87)\end{array}$ & $\begin{array}{l}12 \\
(1.8,22.0)\end{array}$ & $\begin{array}{l}-5 \\
(84)\end{array}$ & $\begin{array}{l}-13 \\
(39)\end{array}$ & $\begin{array}{l}8 \\
(-10.3,25.7)\end{array}$ \\
\hline No & $\begin{array}{l}-60 \\
(28 I)\end{array}$ & $\begin{array}{l}-46 \\
(268)\end{array}$ & $\begin{array}{l}-14 \\
(-21.0,-7.3)\end{array}$ & $\begin{array}{l}-10 \\
(346)\end{array}$ & $\begin{array}{l}-15 \\
(333)\end{array}$ & $\begin{array}{l}5 \\
(-0.3,9.5)\end{array}$ & $\begin{array}{l}-12 \\
(216)\end{array}$ & $\begin{array}{l}-4 \\
(110)\end{array}$ & $\begin{array}{l}-8 \\
(-19.2,2.5)\end{array}$ \\
\hline $\begin{array}{l}\text { Treatment-by-subgroup } \\
\text { interaction } \\
\text { CV risk factors }\end{array}$ & $P=0.22$ & & & $P=0.20$ & & & $P=0.13$ & & \\
\hline$\geq 2$ & $\begin{array}{l}-61 \\
(127)\end{array}$ & $\begin{array}{l}-47 \\
(124)\end{array}$ & $\begin{array}{l}-14 \\
(-24.2,5.19)\end{array}$ & $\begin{array}{l}-8 \\
(257)\end{array}$ & $\begin{array}{l}-16 \\
(272)\end{array}$ & $\begin{array}{l}8 \\
(2.2,13.3)\end{array}$ & $\begin{array}{l}-4 \\
(144)\end{array}$ & $\begin{array}{l}-10 \\
(80)\end{array}$ & $\begin{array}{l}6 \\
(-7.4,18.4)\end{array}$ \\
\hline$\leq 1$ & $\begin{array}{l}-57 \\
(188)\end{array}$ & $\begin{array}{l}-45 \\
(196)\end{array}$ & $\begin{array}{l}-12 \\
(-20.4,-3.9)\end{array}$ & $\begin{array}{l}-11 \\
(163)\end{array}$ & $\begin{array}{l}-14 \\
(148)\end{array}$ & $\begin{array}{l}3 \\
(-4.1,10.4)\end{array}$ & $\begin{array}{l}-16 \\
(156)\end{array}$ & $\begin{array}{l}-2 \\
(69)\end{array}$ & $\begin{array}{l}-14 \\
(-27.0,-0.3)\end{array}$ \\
\hline $\begin{array}{l}\text { Treatment-by-subgroup } \\
\text { interaction } \\
\text { Hypertension }\end{array}$ & $P=0.77$ & & & $P=0.32$ & & & $P=0.04$ & & \\
\hline Yes & $\begin{array}{l}-60 \\
(158)\end{array}$ & $\begin{array}{l}-45 \\
(169)\end{array}$ & $\begin{array}{l}-14 \\
(-23.3,-5.4)\end{array}$ & $\begin{array}{l}-9 \\
(310)\end{array}$ & $\begin{array}{l}-16 \\
(304)\end{array}$ & $\begin{array}{l}8 \\
(2.4,12.7)\end{array}$ & $\begin{array}{l}-9 \\
(23 I)\end{array}$ & $\begin{array}{l}-8 \\
(112)\end{array}$ & $\begin{array}{l}-1 \\
(-11.2,10.2)\end{array}$ \\
\hline No & $\begin{array}{l}-58 \\
(157)\end{array}$ & $\begin{array}{l}-47 \\
(150)\end{array}$ & $\begin{array}{l}-11 \\
(-20.7,-2.2)\end{array}$ & $\begin{array}{l}-12 \\
(109)\end{array}$ & $\begin{array}{l}-14 \\
(116)\end{array}$ & $\begin{array}{l}2 \\
(-6.4,10.6)\end{array}$ & $\begin{array}{l}-15 \\
(67)\end{array}$ & $\begin{array}{l}-1 \\
(36)\end{array}$ & $\begin{array}{l}-15 \\
(-33.8,4.6)\end{array}$ \\
\hline $\begin{array}{l}\text { Treatment-by-subgroup } \\
\text { interaction } \\
\text { Statin use }\end{array}$ & $P=0.66$ & & & $P=0.29$ & & & $P=0.21$ & & \\
\hline $\begin{array}{l}\text { Statin use } \\
\text { Yes }\end{array}$ & $\begin{array}{l}-55 \\
(19)\end{array}$ & $\begin{array}{l}-49 \\
(27)\end{array}$ & $\begin{array}{l}-7 \\
(-30.8,17.7)\end{array}$ & $\begin{array}{l}-9 \\
(175)\end{array}$ & $\begin{array}{l}-18 \\
(167)\end{array}$ & $\begin{array}{l}10 \\
(2.8,16.6)\end{array}$ & $\begin{array}{l}-18 \\
(102)\end{array}$ & $\begin{array}{l}-9 \\
(71)\end{array}$ & $\begin{array}{l}-9 \\
(-23.3,5.4)\end{array}$ \\
\hline No & $\begin{array}{l}-59 \\
(296)\end{array}$ & $\begin{array}{l}-46 \\
(293)\end{array}$ & $\begin{array}{l}-13 \\
(-20.1,-6.8)\end{array}$ & $\begin{array}{l}-10 \\
(245)\end{array}$ & $\begin{array}{l}-14 \\
(253)\end{array}$ & $\begin{array}{l}4 \\
(-2.1,9.4)\end{array}$ & $\begin{array}{l}-7 \\
(198)\end{array}$ & $\begin{array}{l}-4 \\
(78)\end{array}$ & $\begin{array}{l}-2 \\
(-14.8,10.0)\end{array}$ \\
\hline $\begin{array}{l}\text { Treatment-by-subgroup } \\
\text { interaction }\end{array}$ & $P=0.59$ & & & $P=0.19$ & & & $P=0.50$ & & \\
\hline
\end{tabular}

Note: Data from Minervini et $\mathrm{al}^{33}$ and Cook et al. ${ }^{36}$

Abbreviations: $\mathrm{Cl}$, confidence interval; CV, cardiovascular; CVD, cardiovascular disease; FPG, fasting plasma glucose; GLIP, glipizide; INS, insulin; MET, metformin; $\mathrm{PBO}$, placebo; SAXA, saxagliptin. 
to insulin study. This appears to be the result of a greater reduction from baseline in placebo-treated patients with two or more cardiovascular risk factors versus those with no more than one cardiovascular risk factor. The change from baseline in $\mathrm{HbA}_{1 \mathrm{c}}$ with saxagliptin in this study was similar in the two risk groups. Changes from baseline in FPG with saxagliptin were greater than those with placebo in the add-on to metformin study (Table 4), less with saxagliptin compared with glipizide, and similar with saxagliptin and placebo in the add-on to insulin study. Similar to the $\mathrm{HbA}_{1 \mathrm{c}}$ analysis, a greater reduction from baseline in FPG in placebotreated patients with two or more cardiovascular risk factors versus those with no more than one cardiovascular risk factor resulted in a suggestion of a treatment-by-subgroup interaction in the add-on to insulin study. In most subgroups in the add-on to metformin and add-on to insulin studies, more patients treated with saxagliptin than placebo achieved $\mathrm{HbA}_{1 \mathrm{c}}<7 \%$ (Table 5). Similar proportions of patients in the saxagliptin versus glipizide study achieved $\mathrm{HbA}_{1 \mathrm{c}}<7 \%$ across the subgroups.

\section{Safety}

In the five-study pool, rates of one or more adverse events for saxagliptin and placebo were similar in each of the subgroups and ranged from $68 \%$ to $77 \%$ (Table 6 ). The proportion of patients with serious adverse events ranged from $2 \%$ to $7 \%$ across subgroups, with higher rates in patients with a history of CVD. The incidence of serious adverse events was similar or lower with saxagliptin compared with placebo. Reported hypoglycemic events ranged from $6 \%$ to $11 \%$ across subgroups. The rate of confirmed hypoglycemic events was $<1 \%$ in all groups except the placebo group with a history of CVD ( $2 \%$; Table 6$)$.

In the three-study side-by-side analysis, rates of adverse events were comparable between saxagliptin and placebo across all subgroups (Table 7). There were no cases of confirmed hypoglycemia with saxagliptin in any of the cardiovascular subgroups in the add-on to metformin study or in the glipizide study. As expected, the incidence of confirmed hypoglycemia was higher in the add-on to insulin study, but was generally similar across subgroups.

\section{Efficacy and safety of saxagliptin in patients with high Framingham I 0-year cardiovascular risk scores}

Individuals with T2DM are at high risk for development of CVD. ${ }^{6,7}$ Therefore, the efficacy and safety of saxagliptin were analyzed in patients stratified by Framingham 10-year

Table 5 Proportion of patients with cardiovascular disease history or cardiovascular risk factors achieving $\mathrm{Hb} \mathrm{A}_{\mathrm{lc}}<7.0 \%$ : three sideby-side studies

\begin{tabular}{|c|c|c|c|c|c|c|c|c|c|}
\hline & \multicolumn{9}{|c|}{ Patients achieving $\mathbf{H b A}_{\mathrm{lc}}<\mathbf{7 . 0 \%} \%(\mathrm{n} / \mathrm{N})$} \\
\hline & $\begin{array}{l}\text { SAXA + } \\
\text { MET }\end{array}$ & $\begin{array}{l}\text { PBO + } \\
\text { MET }\end{array}$ & $\begin{array}{l}\text { Difference } \\
(95 \% \mathrm{Cl})\end{array}$ & $\begin{array}{l}\text { SAXA + } \\
\text { MET }\end{array}$ & $\begin{array}{l}\text { GLIP + } \\
\text { MET }\end{array}$ & $\begin{array}{l}\text { Difference } \\
(95 \% \mathrm{Cl})\end{array}$ & $\begin{array}{l}\text { SAXA + } \\
\text { INS } \pm \text { MET }\end{array}$ & $\begin{array}{l}\text { PBO + INS } \\
\pm \text { MET }\end{array}$ & $\begin{array}{l}\text { Difference } \\
(95 \% \mathrm{Cl})\end{array}$ \\
\hline \multicolumn{10}{|c|}{ CVD history } \\
\hline Yes & $\begin{array}{l}41 \\
(13 / 32)\end{array}$ & $\begin{array}{l}35 \\
(18 / 52)\end{array}$ & $\begin{array}{l}6 \\
(-16.0,27.7)\end{array}$ & $\begin{array}{l}47 \\
(36 / 76)\end{array}$ & $\begin{array}{l}55 \\
(49 / 89)\end{array}$ & $\begin{array}{l}-8 \\
(-22.8,7.7)\end{array}$ & $\begin{array}{l}13 \\
(11 / 84)\end{array}$ & $\begin{array}{l}10 \\
(4 / 39)\end{array}$ & $\begin{array}{l}3 \\
(-12.0,17.6)\end{array}$ \\
\hline No & $\begin{array}{l}63 \\
(173 / 274)\end{array}$ & $\begin{array}{l}42 \\
(110 / 261)\end{array}$ & $\begin{array}{l}21 \\
(12.6,29.2)\end{array}$ & $\begin{array}{l}56 \\
(193 / 347)\end{array}$ & $\begin{array}{l}57 \\
(191 / 334)\end{array}$ & $\begin{array}{l}-2 \\
(-9.1,6.0)\end{array}$ & $\begin{array}{l}19 \\
(4 \mid / 216)\end{array}$ & $\begin{array}{l}6 \\
(6 / 1 / 0)\end{array}$ & $\begin{array}{l}14 \\
(6.7,20.4)\end{array}$ \\
\hline \multicolumn{10}{|c|}{$\mathrm{CV}$ risk factors } \\
\hline$\geq 2$ & $\begin{array}{l}63 \\
(78 / 124)\end{array}$ & $\begin{array}{l}48 \\
(59 / 124)\end{array}$ & $\begin{array}{l}15 \\
(2.5,27.8)\end{array}$ & $\begin{array}{l}54 \\
(140 / 259)\end{array}$ & $\begin{array}{l}59 \\
(160 / 273)\end{array}$ & $\begin{array}{l}-5 \\
(-13.0,4.0)\end{array}$ & $\begin{array}{l}17 \\
(25 / 145)\end{array}$ & $\begin{array}{l}10 \\
(8 / 80)\end{array}$ & $\begin{array}{l}7 \\
(-2.5,17.0)\end{array}$ \\
\hline$\leq 1$ & $\begin{array}{l}59 \\
(108 / 182)\end{array}$ & $\begin{array}{l}37 \\
(69 / 189)\end{array}$ & $\begin{array}{l}23 \\
(12.7,32.6)\end{array}$ & $\begin{array}{l}54 \\
(89 / 164)\end{array}$ & $\begin{array}{l}53 \\
(80 / / 50)\end{array}$ & $\begin{array}{l}I \\
(-10.1,12.0)\end{array}$ & $\begin{array}{l}17 \\
(27 / 155)\end{array}$ & $\begin{array}{l}3 \\
(2 / 69)\end{array}$ & $\begin{array}{l}15 \\
(7.5,21.5)\end{array}$ \\
\hline \multicolumn{10}{|c|}{ Hypertension } \\
\hline Yes & $\begin{array}{l}63 \\
(97 / 154)\end{array}$ & $\begin{array}{l}44 \\
(74 / 167)\end{array}$ & $\begin{array}{l}19 \\
(7.8,29.3)\end{array}$ & $\begin{array}{l}54 \\
(168 / 3 \mid 3)\end{array}$ & $\begin{array}{l}61 \\
(185 / 305)\end{array}$ & $\begin{array}{l}-7 \\
(-14.8,1.0)\end{array}$ & $\begin{array}{l}17 \\
(40 / 232)\end{array}$ & $\begin{array}{l}8 \\
(9 / 1 / 2)\end{array}$ & $\begin{array}{l}9 \\
(1.4,17.0)\end{array}$ \\
\hline No & $\begin{array}{l}59 \\
(89 / 152)\end{array}$ & $\begin{array}{l}37 \\
(53 / 145)\end{array}$ & $\begin{array}{l}22 \\
(10.7,33.0)\end{array}$ & $\begin{array}{l}55 \\
(60 / 109)\end{array}$ & $\begin{array}{l}47 \\
(55 / I / 8)\end{array}$ & $\begin{array}{l}8 \\
(-4.7,21.3)\end{array}$ & $\begin{array}{l}17 \\
(11 / 66)\end{array}$ & $\begin{array}{l}3 \\
(1 / 36)\end{array}$ & $\begin{array}{l}14 \\
(3.9,23.8)\end{array}$ \\
\hline \multicolumn{10}{|c|}{ Statin use } \\
\hline Yes & $\begin{array}{l}63 \\
(12 / 19)\end{array}$ & $\begin{array}{l}37 \\
(10 / 27)\end{array}$ & $\begin{array}{l}26 \\
(-3.8,52.6)\end{array}$ & $\begin{array}{l}51 \\
(91 / 177)\end{array}$ & $\begin{array}{l}58 \\
(98 / 169)\end{array}$ & $\begin{array}{l}7 \\
(-17.1,4.0)\end{array}$ & $\begin{array}{l}20 \\
(20 / 102)\end{array}$ & $\begin{array}{l}\text { II } \\
(8 / 71)\end{array}$ & $\begin{array}{l}8 \\
(-2.5,19.2)\end{array}$ \\
\hline No & $\begin{array}{l}61 \\
(174 / 287)\end{array}$ & $\begin{array}{l}41 \\
(118 / 286)\end{array}$ & $\begin{array}{l}19 \\
(11.1,27.4)\end{array}$ & $\begin{array}{l}56 \\
(138 / 246)\end{array}$ & $\begin{array}{l}56 \\
(142 / 254)\end{array}$ & $\begin{array}{l}0.2 \\
(-8.6,9.0)\end{array}$ & $\begin{array}{l}16 \\
(32 / 198)\end{array}$ & $\begin{array}{l}3 \\
(2 / 78)\end{array}$ & $\begin{array}{l}14 \\
(7.3,19.9)\end{array}$ \\
\hline
\end{tabular}

Note: Data from Minervini et $\mathrm{al}^{33}$ and Cook et al..$^{36}$

Abbreviations: $\mathrm{Cl}$, confidence interval; $\mathrm{CV}$, cardiovascular; CVD, cardiovascular disease; GLIP, glipizide; HbA, glycated hemoglobin; INS, insulin; MET, metformin; n/N, number of patients achieving target/total number of patients in that group; PBO, placebo; SAXA, saxagliptin. 


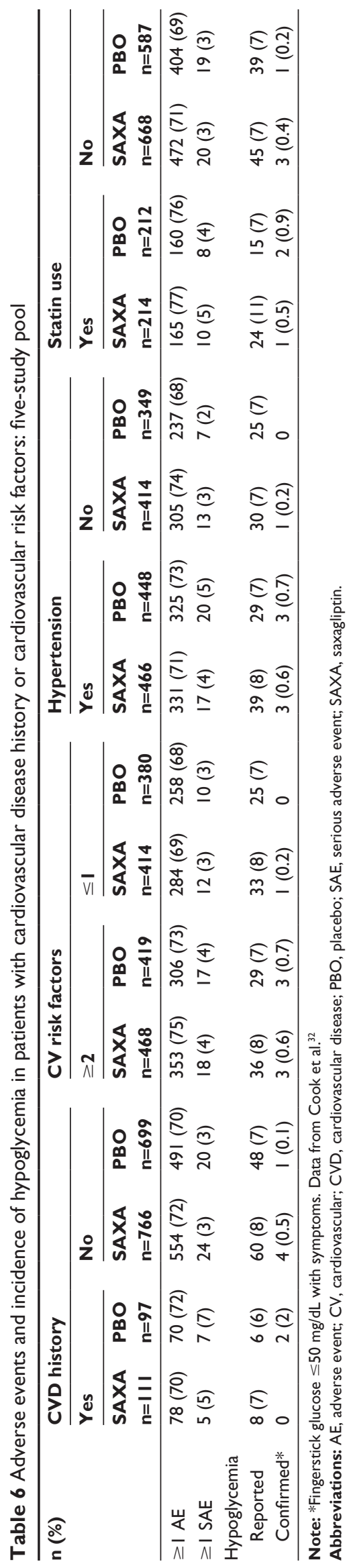

cardiovascular risk score ${ }^{37} \geq 20 \%$ versus $<20 \%$ from the same five-study pool discussed earlier. ${ }^{38}$ The Framingham cardiovascular risk score is a multivariable risk prediction tool that estimates CVD risk in patients based on multiple risk factors, such as age, total cholesterol, high-density lipoprotein cholesterol, systolic blood pressure, smoking, and diabetes status, and can be used as a guide for preventive care ${ }^{37}$ In this analysis, efficacy variables were adjusted mean change from baseline $\mathrm{HbA}_{1 \mathrm{c}}$, FPG, and 120-minute PPG, and the proportion of patients achieving $\mathrm{HbA}_{1 \mathrm{c}}<7 \%$ at week 24 . In patients with a Framingham 10-year cardiovascular risk score $\geq 20 \%$ versus $<20 \%$, mean age was higher (range across treatment groups, 60.0-60.6 years versus 49.9-50.1 years, respectively), mean duration of T2DM was longer (range across groups, 6.0 years versus $4.3-4.9$ years), and a smaller proportion were women $(32.1 \%-34.2 \%$ versus $68.3 \%-68.9 \%)$.

\section{Efficacy}

Change from baseline $\mathrm{HbA}_{1 \mathrm{c}}$ at week 24 was greater with saxagliptin compared with placebo in both patients with a Framingham cardiovascular risk score $\geq 20 \%$ and $<20 \%$. There was a significant treatment-by-subgroup interaction $(P=0.01)$ in patients with a Framingham risk score $\geq 20 \%$ versus $<20 \%$, indicating a greater treatment effect of saxagliptin in patients with a risk score $\geq 20 \%$ (Table 8 ). Improvements from baseline in FPG and PPG were greater with saxagliptin versus placebo in both cardiovascular risk groups, with no evidence of a treatment-by-subgroup interaction (Table 8). In both cardiovascular risk groups, the $\mathrm{HbA}_{1 \mathrm{c}}$ target of $<7 \%$ at week 24 was achieved by more patients treated with saxagliptin compared with placebo (Table 8).

\section{Safety}

Rates of adverse events and serious adverse events were similar across Framingham risk score groups and treatment groups (Table 9). The incidence of reported and confirmed hypoglycemia was low in both risk score groups and similar between saxagliptin and placebo.

\section{Efficacy and safety of saxagliptin in patients with or without concomitant statin use}

The American Diabetes Association recommends that statin therapy together with lifestyle changes be used in all patients with diabetes and CVD, regardless of baseline lipid values. ${ }^{39}$ Statin therapy is also recommended for patients with diabetes who are aged $>40$ years without CVD and have one or more 
Table 7 Adverse events and confirmed hypoglycemia in patients with cardiovascular disease history or cardiovascular risk factors: three side-by-side studies

\begin{tabular}{|c|c|c|c|c|c|c|}
\hline Subgroup & $\begin{array}{l}\text { SAXA + MET } \\
n=320\end{array}$ & $\begin{array}{l}\text { PBO + MET } \\
n=328\end{array}$ & $\begin{array}{l}\text { SAXA + MET } \\
n=428\end{array}$ & $\begin{array}{l}\text { GLIP + MET } \\
n=430\end{array}$ & $\begin{array}{l}\text { SAXA + INS } \pm \text { MET } \\
n=304\end{array}$ & $\begin{array}{l}P B O+I N S \pm \text { MET } \\
n=I 5 I\end{array}$ \\
\hline \multicolumn{7}{|l|}{ CVD history } \\
\hline Yes & $\mathrm{n}=34$ & $n=53$ & $\mathrm{n}=79$ & $n=91$ & $n=85$ & $n=39$ \\
\hline$\geq \mathrm{IAE}$ & $20(59)$ & $31(59)$ & $39(49)$ & $61(67)$ & $40(47)$ & $22(56)$ \\
\hline$\geq I \mathrm{SAE}$ & $2(6)$ & $6(11)$ & $8(10)$ & $14(15)$ & $3(4)$ & $4(10)$ \\
\hline Confirmed hypoglycemia* & 0 & 0 & 0 & $6(7)$ & I (I) & 0 \\
\hline No & $\mathrm{n}=286$ & $\mathrm{n}=275$ & $n=349$ & $n=339$ & $n=219$ & $\mathrm{n}=\mathrm{I} \mid 2$ \\
\hline$\geq \mathrm{IAE}$ & $158(55)$ & I6I (59) & $224(64)$ & $233(69)$ & $133(6 \mid)$ & $68(6 I)$ \\
\hline$\geq I \mathrm{SAE}$ & $6(2)$ & $2(1)$ & $31(9)$ & $21(6)$ & $9(4)$ & $3(3)$ \\
\hline Confirmed hypoglycemia & 0 & I (0) & 0 & $29(9)$ & $15(7)$ & $6(5)$ \\
\hline \multicolumn{7}{|l|}{ CV risk factor } \\
\hline$\geq 2$ & $n=129$ & $\mathrm{n}=127$ & $n=262$ & $\mathrm{n}=277$ & $n=145$ & $n=81$ \\
\hline$\geq \mathrm{IAE}$ & $81(63)$ & $76(60)$ & $168(64)$ & $200(72)$ & $78(54)$ & $47(58)$ \\
\hline$\geq I \mathrm{SAE}$ & $5(4)$ & $2(2)$ & $28(\mathrm{II})$ & $25(9)$ & $7(5)$ & $5(6)$ \\
\hline Confirmed hypoglycemia & 0 & 0 & 0 & $28(10)$ & $7(5)$ & $3(4)$ \\
\hline$\leq 1$ & $n=|9|$ & $n=201$ & $\mathrm{n}=166$ & $\mathrm{n}=153$ & $n=159$ & $\mathrm{n}=70$ \\
\hline$\geq \mathrm{IAE}$ & $97(5 \mathrm{I})$ & $116(58)$ & $95(57)$ & $94(61)$ & $95(60)$ & $43(61)$ \\
\hline$\geq I S A E$ & $3(2)$ & $6(3)$ & II (7) & $10(7)$ & $5(3)$ & $2(3)$ \\
\hline Confirmed hypoglycemia & 0 & $\mathrm{I}(\mathrm{I})$ & 0 & $7(5)$ & $9(6)$ & $3(4)$ \\
\hline \multicolumn{7}{|l|}{ Hypertension } \\
\hline Yes & $n=160$ & $n=172$ & $n=318$ & $n=311$ & $\mathrm{n}=234$ & $\mathrm{n}=113$ \\
\hline$\geq \mathrm{IAE}$ & $91(57)$ & I0I (59) & $196(62)$ & $208(67)$ & $126(54)$ & $63(56)$ \\
\hline$\geq I S A E$ & $5(3)$ & $6(4)$ & $32(10)$ & $29(9)$ & $7(3)$ & $5(4)$ \\
\hline Confirmed hypoglycemia & 0 & 0 & 0 & $26(8)$ & II (5) & $3(3)$ \\
\hline No & $n=160$ & $n=155$ & $\mathrm{n}=109$ & $\mathrm{n}=119$ & $\mathrm{n}=68$ & $n=37$ \\
\hline$\geq \mathrm{IAE}$ & $87(54)$ & $90(58)$ & $67(62)$ & $86(72)$ & $45(66)$ & $27(73)$ \\
\hline$\geq I \mathrm{SAE}$ & $3(2)$ & $2(1)$ & $7(6)$ & $6(5)$ & $4(6)$ & $2(5)$ \\
\hline Confirmed hypoglycemia & 0 & $I(I)$ & 0 & $9(8)$ & $5(7)$ & $3(8)$ \\
\hline \multicolumn{7}{|l|}{ Statin use } \\
\hline Yes & $\mathrm{n}=20$ & $\mathrm{n}=27$ & $\mathrm{n}=180$ & $n=172$ & $n=103$ & $n=71$ \\
\hline$\geq \mathrm{IAE}$ & $13(65)$ & $17(63)$ & $121(67)$ & $122(7 \mid)$ & $57(55)$ & $48(68)$ \\
\hline$\geq I \mathrm{SAE}$ & 0 & $2(7)$ & $23(13)$ & $13(8)$ & $6(6)$ & $5(7)$ \\
\hline Confirmed hypoglycemia & 0 & 0 & 0 & $16(9)$ & $8(8)$ & $4(6)$ \\
\hline No & $n=300$ & $n=301$ & $\mathrm{n}=248$ & $\mathrm{n}=258$ & $n=201$ & $n=80$ \\
\hline$\geq \mathrm{IAE}$ & $165(55)$ & $175(58)$ & $142(57)$ & $172(67)$ & $116(58)$ & $42(53)$ \\
\hline$\geq I S A E$ & $8(3)$ & $6(2)$ & $16(7)$ & $22(9)$ & $6(3)$ & $2(3)$ \\
\hline Confirmed hypoglycemia & 0 & $I(0)$ & 0 & $19(7)$ & $8(4)$ & $2(3)$ \\
\hline
\end{tabular}

Notes: Data from Minervini et $\mathrm{al}^{33}$ and Cook et al. ${ }^{36}$ Data are $\mathrm{n}(\%)$. *Fingerstick glucose $\leq 50 \mathrm{mg} / \mathrm{dL}$ with symptoms.

Abbreviations: AE, adverse event; CV, cardiovascular; CVD, cardiovascular disease; GLIP, glipizide; INS, insulin; MET, metformin; PBO, placebo; SAE, serious adverse event; SAXA, saxagliptin.

CVD risk factors. Statin use in patients with T2DM is high. In an analysis of a primary care network, $63 \%$ of patients with T2DM were prescribed a statin..$^{40} \mathrm{In}$ this analysis, the efficacy and safety of saxagliptin 2.5 and $5 \mathrm{mg} /$ day, compared with placebo, in patients with or without concomitant statin use were analyzed from data pooled from nine placebo-controlled Phase III studies with a primary $24-w e e k$ treatment period. ${ }^{41}$ Studies included in the nine-study pool were four saxagliptin monotherapy trials, ${ }^{24,25,42,43}$ two trials of saxagliptin as add-on to metformin, ${ }^{26,44}$ and one each of saxagliptin as add-on to a sulfonylurea, ${ }^{27}$ thiazolidinedione, ${ }^{28}$ and insulin \pm metformin. ${ }^{29}$ Efficacy end points were change from baseline to week 24 in $\mathrm{HbA}_{1 \mathrm{c}}$, FPG, and 120-minute PPG, and the proportion of patients achieving $\mathrm{HbA}_{1 \mathrm{c}}<7 \%$ at week 24 .

Analyses of safety were performed on an eleven-study pool of 24-week clinical trials and an additional 20-study pool. The eleven-study safety pool included data for saxagliptin 2.5 and $5 \mathrm{mg} /$ day and placebo or control from the nine studies in the efficacy pool plus two 24-week, randomized controlled studies of saxagliptin as add-on therapy 
Table 8 Efficacy of saxagliptin in patients with high Framingham 10-year cardiovascular risk: five-study pool

\begin{tabular}{|c|c|c|c|c|c|c|c|c|}
\hline & \multicolumn{6}{|c|}{ Adjusted mean change from baseline } & \multirow{2}{*}{\multicolumn{2}{|c|}{$\begin{array}{l}\text { Patients achieving } \\
\mathrm{HbA}_{\mathrm{Ic}}<7.0 \%, \%(\mathrm{n} / \mathrm{N})\end{array}$}} \\
\hline & \multicolumn{2}{|l|}{$\mathrm{HbA}_{\mathrm{Ic}}, \%(\mathrm{n})$} & \multicolumn{2}{|c|}{ FPG, mg/dL (n) } & \multicolumn{2}{|c|}{ PPG, mg/dL (n) } & & \\
\hline & SAXA & PBO & SAXA & PBO & SAXA & PBO & SAXA & PBO \\
\hline Framingham CV risk $<20 \%$ & $-0.61(443)$ & $-0.07(390)$ & $-13(447)$ & $0.2(396)$ & $-50(347)$ & $-9(297)$ & $35(154 / 443)$ & $19(73 / 390)$ \\
\hline $\begin{array}{l}\text { Difference versus PBO } \\
(95 \% \mathrm{Cl})\end{array}$ & \multicolumn{2}{|c|}{$-0.54(-0.67,-0.4 \mathrm{I})$} & \multicolumn{2}{|c|}{$-13(-18.1,-7.8)$} & \multicolumn{2}{|c|}{$-42(-5 \mid .7,-31.6)$} & \multicolumn{2}{|l|}{$14(8.1,20.7)$} \\
\hline Framingham $\mathrm{CV}$ risk $\geq 20 \%$ & $-0.81(400)$ & $0(374)$ & $-16(404)$ & $0.6(374)$ & $-56(306)$ & $-15(278)$ & $38(152 / 400)$ & $19(72 / 374)$ \\
\hline $\begin{array}{l}\text { Difference versus PBO } \\
(95 \% \mathrm{Cl})\end{array}$ & \multicolumn{2}{|c|}{$-0.8 \mathrm{I}(-0.94,-0.67)$} & \multicolumn{2}{|c|}{$-16(-21.5,-10.8)$} & \multicolumn{2}{|c|}{$-4 \mid(-5 \mid .3,-30.2)$} & \multirow[t]{2}{*}{$18(\mid 1.4,24.6)$} & \\
\hline Treatment-by-subgroup interaction & $P=0.01$ & & $P=0.55$ & & $P=0.85$ & & & \\
\hline
\end{tabular}

Note: Data from Bonora et al. ${ }^{38}$

Abbreviations: $\mathrm{Cl}$, confidence interval; CV, cardiovascular; FPG, fasting plasma glucose; $\mathrm{HbA}_{\mathrm{lc}}$, glycated hemoglobin; $\mathrm{n} / \mathrm{N}$, number of patients achieving target/total number of patients in that group; PBO, placebo; PPG, postprandial glucose; SAXA, saxagliptin.

to metformin ${ }^{34,45}$ (only the saxagliptin + metformin and metformin + placebo arms were included in the analyses). The 20 -study pool included data for all saxagliptin doses $(2.5,5$, $10,20,40$, and $100 \mathrm{mg} /$ day) and placebo or control from the eleven studies in the 24-week safety pool and nine randomized clinical trials of 4-206 weeks' duration for saxagliptin as monotherapy ${ }^{46-49}$ or as add-on to metformin. ${ }^{35,50-54}$

Patient demographics and baseline disease characteristics were generally consistent between treatment groups within the patient subpopulations of any statin use versus no statin use. However, compared with patients not using statins, patients receiving statins were slightly older ( 58 years versus $53-54$ years) and more likely to be white (68\%-77\% versus $35 \%-65 \%)$, be men $(50 \%-56 \%$ versus $45 \%-49 \%)$, have a body mass index $\geq 30 \mathrm{~kg} / \mathrm{m}^{2}$ (53\%-59\% versus 31\%-49\%), and have a diabetes duration $\geq 5$ years $(50 \%-57 \%$ versus $34 \%-42 \%)^{41}$

\section{Efficacy}

Significantly greater adjusted mean reductions from baseline were observed with saxagliptin versus control (Table 10). ${ }^{41}$

Table 9 Adverse events and confirmed hypoglycemia in patients with high Framingham 10-year cardiovascular risk

\begin{tabular}{|c|c|c|c|c|}
\hline & \multicolumn{4}{|c|}{ Framingham I0-year CV risk score } \\
\hline & \multicolumn{2}{|l|}{$<\mathbf{2 0} \%$} & \multicolumn{2}{|l|}{$\geq \mathbf{2 0} \%$} \\
\hline & $\begin{array}{l}\text { SAXA } \\
(n=454)\end{array}$ & $\begin{array}{l}\text { PBO } \\
(n=404)\end{array}$ & $\begin{array}{l}\text { SAXA } \\
(n=408)\end{array}$ & $\begin{array}{l}\text { PBO } \\
(n=380)\end{array}$ \\
\hline$\geq \mathrm{IAE}$ & $318(70)$ & $275(68)$ & $302(74)$ & $277(73)$ \\
\hline$\geq I \mathrm{SAE}$ & $13(3)$ & $9(2)$ & $16(4)$ & $18(5)$ \\
\hline \multicolumn{5}{|l|}{ Hypoglycemia } \\
\hline Reported & $36(8)$ & $28(7)$ & $29(7)$ & $26(7)$ \\
\hline Confirmed* & $2(0)$ & 0 & $2(1)$ & $3(1)$ \\
\hline
\end{tabular}

Notes: Data are $\mathrm{n}(\%)$. *Fingerstick glucose $\leq 50 \mathrm{mg} / \mathrm{dL}$ with symptoms. Data from Bonora et al. ${ }^{38}$

Abbreviations: $\mathrm{AE}$, adverse event; $\mathrm{CV}$, cardiovascular; $\mathrm{PBO}$, placebo; $\mathrm{SAE}$, serious adverse event; SAXA, saxagliptin.
Also, greater proportions of patients achieved $\mathrm{HbA}_{1 \mathrm{c}}<7 \%$ with saxagliptin versus control, regardless of statin use (Table 10). There were no treatment-by-subgroup interactions detected for $\mathrm{HbA}_{1 \mathrm{c}}$, FPG, or PPG between patients with or without baseline statin use.

\section{Safety}

In the eleven-study pool, the proportion of patients with one or more adverse events was slightly higher in patients using statins (63\%-78\%) compared with those with no statin use (55\%-71\%; Table 11). The incidence of one or more adverse events appeared to be higher with saxagliptin $2.5 \mathrm{mg} /$ day than with saxagliptin $5 \mathrm{mg} /$ day and control, irrespective of statin use. The incidence of reported hypoglycemia was similar across treatment groups but was slightly higher in patients with any statin use (range across treatment groups, $10 \%-12 \%$ ) compared with patients with no statin use (4\%-7\%; Table 11). The incidence of events of confirmed hypoglycemia was low and similar in patients with any statin use $(0 \%-2 \%)$ and with no statin use $(0 \%-1 \%)$.

\section{Discussion}

Individuals with T2DM are at high risk for $\mathrm{CVD}^{6,7}$ and often have multiple CVD risk factors. ${ }^{1-4}$ Therefore, it is important to consider the effects of glucose-lowering medications not only on glycemic control, but also on cardiovascular risk. ${ }^{55,56}$ This overview of published analyses of saxagliptin clinical trials in patients with T2DM demonstrates that saxagliptin consistently improved glycemic control, compared with placebo, as assessed by reductions from baseline in $\mathrm{HbA}_{1 \mathrm{c}}$, FPG, and PPG, and the proportion of patients achieving a therapeutic goal of $\mathrm{HbA}_{1 \mathrm{c}}<7 \%$, regardless of the presence or absence of baseline CVD history, hypertension, statin use, number of cardiovascular risk factors, or high Framingham 10-year cardiovascular 


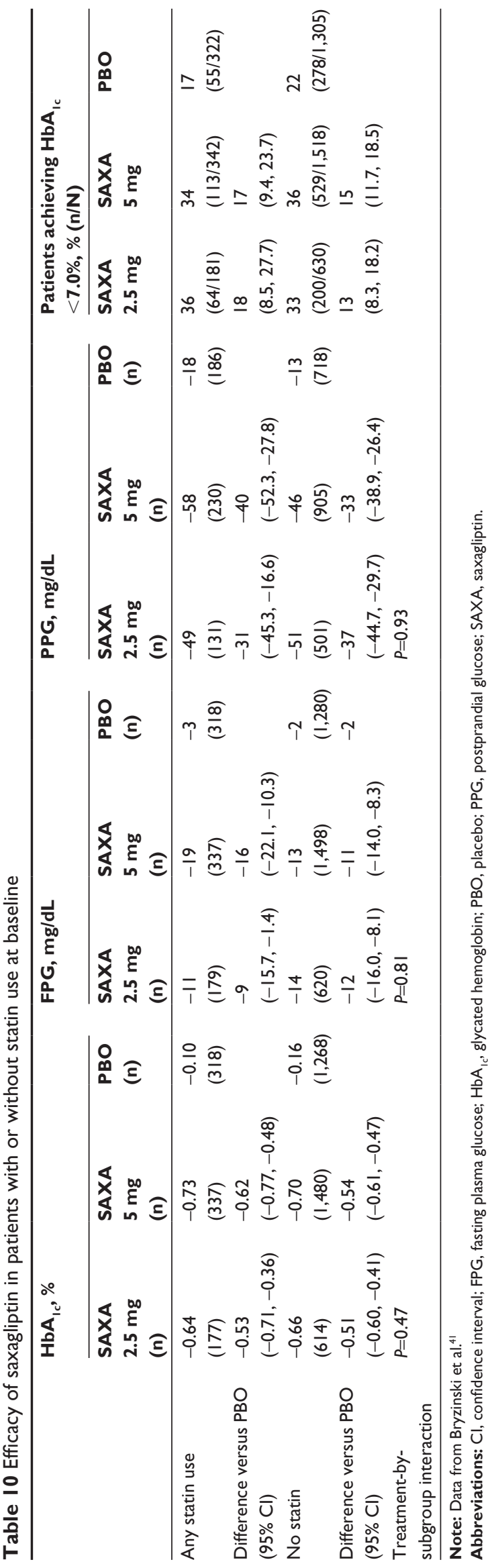

risk score. Moreover, in all analyses, including studies up to 206 weeks in duration, saxagliptin was generally well tolerated in patients with and without a history of CVD or cardiovascular risk factors. The frequencies of adverse events, serious adverse events, and confirmed hypoglycemia were comparable across treatment and cardiovascular risk subgroups. These results are consistent with the overall safety profile of the DPP-4 inhibitor class, as reported by a number of published meta-analyses..$^{57-61}$

The analyses summarized in this review included patients with a history of or risk factors for CVD. Comparable safety data for saxagliptin have recently been reported from a post hoc pooled analysis performed on 20 Phase II/III trials of saxagliptin $(\mathrm{N}=9,156)$ in a more general population of patients with T2DM. The analysis focused on adverse events of special interest, including infections, hypersensitivity, pancreatitis, malignancies, and bone fractures. ${ }^{62}$ In this population, the incidence of death, serious adverse events, discontinuations due to adverse events, pancreatitis, malignancy, and most of the other events of interest were similar in the saxagliptin and control groups. Only the incidence rates for bone fractures and hypersensitivity were higher with saxagliptin compared with control. An additional pooled analysis of the same 20 clinical trials found that saxagliptin was not associated with an increased risk of adjudicated major adverse cardiovascular events (cardiovascular deaths, MI, or stroke), compared with control, and saxagliptin was not associated with an increased risk of nonadjudicated heart failure. ${ }^{63}$

Although the results of this summary and the aforementioned meta-analysis suggest that saxagliptin is effective and well tolerated in patients with T2DM with a history of or risk factors for CVD, all of these analyses are post hoc and, as such, have inherent limitations and can provide only suggestive evidence. Because of concerns over the safety of some antidiabetes medications, ${ }^{64}$ in 2008, the US Food and Drug Administration determined that new antihyperglycemic therapies must demonstrate cardiovascular safety. Two prospective trials designed to evaluate the cardiovascular safety of saxagliptin and alogliptin have recently been published. In the SAVOR (Saxagliptin Assessment of Vascular Outcomes Recorded in Patients With Diabetes Mellitus) trial, ${ }^{65}$ 16,492 patients with T2DM and either established CVD or multiple risk factors for CVD were randomly assigned to receive saxagliptin $5 \mathrm{mg} /$ day (or $2.5 \mathrm{mg} /$ day in patients with an estimated glomerular filtration rate $\leq 50 \mathrm{~mL} / \mathrm{min}$ ) or placebo and were followed for a median of 2.1 years. The primary end point, a composite 
Table I I Adverse events and confirmed hypoglycemia in patients with or without statin use at baseline: eleven-study pool

\begin{tabular}{|c|c|c|c|c|c|c|}
\hline \multirow[t]{3}{*}{ n (\%) } & \multicolumn{3}{|c|}{ Any statin use } & \multicolumn{3}{|c|}{ No statin use } \\
\hline & \multicolumn{2}{|l|}{ SAXA } & \multirow{2}{*}{$\begin{array}{l}\text { PBO } \\
(n=4 \mid 8)\end{array}$} & \multicolumn{2}{|l|}{ SAXA } & \multirow{2}{*}{$\begin{array}{l}\text { PBO } \\
(n=1,676)\end{array}$} \\
\hline & $\begin{array}{l}2.5 \mathrm{mg} \\
(\mathrm{n}=192)\end{array}$ & $\begin{array}{l}5 \mathrm{mg} \\
(\mathrm{n}=436)\end{array}$ & & $\begin{array}{l}2.5 \mathrm{mg} \\
(\mathrm{n}=690)\end{array}$ & $\begin{array}{l}5 \mathrm{mg} \\
(n=I, 89 I)\end{array}$ & \\
\hline$\geq \mathrm{IAE}$ & I50 (78) & $279(64)$ & $264(63)$ & 487 (7I) & $\mathrm{I}, 094(58)$ & 921 (55) \\
\hline$\geq I \mathrm{SAE}$ & II (6) & $19(4)$ & $16(4)$ & $20(3)$ & $57(3)$ & $38(2)$ \\
\hline \multicolumn{7}{|l|}{ Hypoglycemia } \\
\hline Reported & $22(I 2)$ & $50(12)$ & $40(10)$ & $47(7)$ & $107(6)$ & 71 (4) \\
\hline Confirmed* & 0 & $9(2)$ & $10(2)$ & $7(1)$ & $10(1)$ & $4(0)$ \\
\hline
\end{tabular}

Notes: Data from Bryzinski et al. ${ }^{41}$ *Fingerstick glucose $\leq 50 \mathrm{mg} / \mathrm{dL}$ with symptoms.

Abbreviations: AE, adverse event; PBO, placebo; SAE, serious adverse event; SAXA, saxagliptin.

of cardiovascular death, MI, or ischemic stroke, occurred in $7.3 \%$ of patients in the saxagliptin group and a similar proportion $(7.2 \%)$ of those in the placebo group, resulting in a hazard ratio ( $95 \%$ confidence interval [CI]) of 1.00 $(0.89,1.12)$. There was also no difference between the saxagliptin and placebo groups for the major secondary composite end point of cardiovascular death, MI, stroke, hospitalization for unstable angina, hospitalization for coronary revascularization, or hospitalization for heart failure (hazard ratio $1.02 ; 95 \%$ CI $0.94,1.11$ ). A secondary end point of all-cause mortality occurred in $4.9 \%$ of patients in the saxagliptin group compared with $4.2 \%$ in the placebo group (hazard ratio $1.11 ; 95 \%$ CI $0.96,1.27$; $P=0.15$ ). A subanalysis of the individual components of the secondary composite end point revealed that a greater number of patients receiving saxagliptin compared with those receiving placebo were hospitalized for heart failure (3.5\% versus $2.8 \%$; hazard ratio 1.27 ; $95 \%$ CI 1.07, 1.51 ; $P=0.007)$. The numbers of patients with hypersensitivity, infections, bone fractures, cancer, and pancreatitis were low and similar between the saxagliptin and placebo groups. A greater number of patients in the saxagliptin group (15.3\%) versus the placebo group (13.4\%) had at least one hypoglycemic event. After 2 years, $\mathrm{HbA}_{1 \mathrm{c}}$ and FPG were significantly lower with saxagliptin compared with placebo ( $7.5 \%$ versus $7.8 \%$, respectively; $153 \mathrm{mg} / \mathrm{dL}$ versus $158 \mathrm{mg} / \mathrm{dL} ; P<0.001$ for both). Also, a significantly $(P<0.001)$ greater proportion of patients achieved an $\mathrm{HbA}_{1 \mathrm{c}}$ $<7 \%$ with saxagliptin ( $40 \%$ ) versus placebo $(30 \%)$.

In the second cardiovascular outcomes trial of a DPP-4 inhibitor, ie, EXAMINE (Examination of Cardiovascular Outcomes With Alogliptin Versus Standard of Care), ${ }^{66}$ 5,380 patients with T2DM and either an acute MI or unstable angina requiring hospitalization within the previous 15-90 days were randomized to alogliptin (6.25, 12.25 , or $25 \mathrm{mg}$ /day depending on estimated glomerular filtration rate) or placebo and followed for a median of 18 months. The primary end point was a composite of death from cardiovascular causes, nonfatal MI, or nonfatal stroke, which occurred in a similar proportion of patients receiving alogliptin (11.3\%) and placebo (11.8\%; hazard ratio 0.96; upper boundary of the one-sided repeated CI, 1.16). A post hoc analysis of the composite end point of cardiovascular mortality and hospitalization for heart failure found a numerically greater proportion of patients hospitalized for heart failure in the alogliptin group (3.9\%) than in the placebo group (3.3\%). However, the difference between the groups was not statistically significant (hazard ratio 1.19; $95 \%$ CI $0.90,1.58) .{ }^{67}$ The incidence of serious adverse events, hypoglycemia, and pancreatitis was similar between the alogliptin and placebo groups. Compared with placebo, alogliptin significantly reduced $\mathrm{HbA}_{1 \mathrm{c}}$ (mean difference, $-0.36 \% ; P<0.001)$.

\section{Summary and conclusion}

Because of the high prevalence of CVD in patients with T2DM, antihyperglycemic therapies that improve or at least have no deleterious effects on CVD or cardiovascular risk factors are preferable. ${ }^{68-70}$ The findings to date show that saxagliptin was generally well tolerated and consistently improved glycemic control, as assessed by reductions from baseline in $\mathrm{HbA}_{1 \mathrm{c}}$, FPG, and $\mathrm{PPG}$, regardless of the presence or absence of baseline CVD history, hypertension, statin use, number of cardiovascular risk factors, or high Framingham 10-year cardiovascular risk score. This overview of the efficacy and safety of saxagliptin in metaanalyses of clinical trials in patients with T2DM and CVD or cardiovascular risk factors and, more importantly, the results of SAVOR, the prospective cardiovascular outcomes trial, demonstrate that saxagliptin appears to be safe and is not associated with an increased risk of CVD, nor does it appear to reduce the incidence of adverse cardiovascular 
events in patients with T2DM and increased cardiovascular risk.

\section{Disclosure}

This study was supported by Bristol-Myers Squibb and AstraZeneca. Dr Toth was involved in all stages of manuscript development and received no honorarium. He is a consultant and member of the speakers' bureau for AstraZeneca. Medical writing support for preparation of this manuscript was provided by Richard Edwards and Janet Matsuura of Complete Healthcare Communications, Inc. (Chadds Ford, PA, USA), with funding from Bristol-Myers Squibb and AstraZeneca. The author reports no other conflicts of interest in this work.

\section{References}

1. Centers for Disease Control and Prevention. National diabetes statistics report: estimates of diabetes and its burden in the United States, 2014. Available from: http://www.cdc.gov/diabetes/pubs/statsreport14/ national-diabetes-report-web.pdf. Accessed September 23, 2014.

2. Gerstein HC, Mann JF, Yi Q, et al. Albuminuria and risk of cardiovascular events, death, and heart failure in diabetic and nondiabetic individuals. JAMA. 2001;286(4):421-426.

3. Mokdad AH, Ford ES, Bowman BA, et al. Prevalence of obesity, diabetes, and obesity-related health risk factors, 2001. JAMA. 2003;289(1):76-79.

4. Mooradian AD. Dyslipidemia in type 2 diabetes mellitus. Nat Clin Pract Endocrinol Metab. 2009;5(3):150-159.

5. Engelgau MM, Geiss LS, Saaddine JB, et al. The evolving diabetes burden in the United States. Ann Intern Med. 2004;140(11):945-950.

6. Fox CS, Coady S, Sorlie PD, et al. Increasing cardiovascular disease burden due to diabetes mellitus: the Framingham Heart Study. Circulation. 2007;115(12):1544-1550.

7. Hu FB, Stampfer MJ, Haffner SM, Solomon CG, Willett WC, Manson JE. Elevated risk of cardiovascular disease prior to clinical diagnosis of type 2 diabetes. Diabetes Care. 2002;25(7):1129-1134.

8. Centers for Disease Control and Prevention. National diabetes fact sheet, 2011: national estimates and general information on diabetes and prediabetes in the United States. Available from: http://www. cdc.gov/diabetes/pubs/pdf/ndfs_2011.pdf. Accessed August 14, 2014.

9. Gerstein HC, Swedberg K, Carlsson J, et al. The hemoglobin A1c level as a progressive risk factor for cardiovascular death, hospitalization for heart failure, or death in patients with chronic heart failure: an analysis of the Candesartan in Heart failure: Assessment of Reduction in Mortality and Morbidity (CHARM) program. Arch Intern Med. 2008;168(15):1699-1704.

10. Selvin E, Marinopoulos S, Berkenblit G, et al. Meta-analysis: glycosylated hemoglobin and cardiovascular disease in diabetes mellitus. Ann Intern Med. 2004;141(6):421-431.

11. Selvin E, Steffes MW, Zhu H, et al. Glycated hemoglobin, diabetes, and cardiovascular risk in nondiabetic adults. $N$ Engl J Med. 2010;362(9): 800-811.

12. Duckworth W, Abraira C, Moritz T, et al. Glucose control and vascular complications in veterans with type 2 diabetes. $N$ Engl J Med. 2009; 360(2):129-139.

13. Gerstein HC, Miller ME, Byington RP, et al. Effects of intensive glucose lowering in type 2 diabetes. N Engl J Med. 2008;358(24):2545-2559.

14. Patel A, MacMahon S, Chalmers J, et al. Intensive blood glucose control and vascular outcomes in patients with type 2 diabetes. $N$ Engl J Med. 2008;358(24):2560-2572.
15. Holman RR, Paul SK, Bethel MA, Matthews DR, Neil HA. 10-year follow-up of intensive glucose control in type 2 diabetes. NEngl J Med. 2008;359(15):1577-1589.

16. Ray KK, Seshasai SR, Wijesuriya S, et al. Effect of intensive control of glucose on cardiovascular outcomes and death in patients with diabetes mellitus: a meta-analysis of randomised controlled trials. Lancet. 2009;373(9677):1765-1772.

17. Gaede P, Lund-Andersen H, Parving HH, Pedersen O. Effect of a multifactorial intervention on mortality in type 2 diabetes. $N$ Engl $J$ Med. 2008;358(6):580-591.

18. Gaede P, Vedel P, Larsen N, Jensen GV, Parving HH, Pedersen O. Multifactorial intervention and cardiovascular disease in patients with type 2 diabetes. N Engl J Med. 2003;348(5):383-393.

19. Good CB. Polypharmacy in elderly patients with diabetes. Diabetes Spectrum. 2002;15(4):240-248.

20. Curkendall SM, Thomas N, Bell KF, Juneau PL, Weiss AJ. Predictors of medication adherence in patients with type 2 diabetes mellitus. Curr Med Res Opin. 2013;29(10):1275-1286.

21. Garber AJ, Abrahamson MJ, Barzilay JI, et al. American Association of Clinical Endocrinologists' comprehensive diabetes management algorithm 2013 consensus statement - executive summary. Endocr Pract. 2013;19(3):536-557.

22. Inzucchi SE, Bergenstal RM, Buse JB, et al. Management of hyperglycemia in type 2 diabetes: a patient-centered approach: position statement of the American Diabetes Association (ADA) and the European Association for the Study of Diabetes (EASD). Diabetes Care. 2012;35(6):1364-1379.

23. Drucker DJ. The role of gut hormones in glucose homeostasis. J Clin Invest. 2007;117(1):24-32.

24. Frederich R, McNeill R, Berglind N, Fleming D, Chen R. The efficacy and safety of the dipeptidyl peptidase-4 inhibitor saxagliptin in treatment-naive patients with type 2 diabetes mellitus: a randomized controlled trial. Diabetol Metab Syndr. 2012;4(1):36.

25. Rosenstock J, Aguilar-Salinas C, Klein E, Nepal S, List J, Chen R. Effect of saxagliptin monotherapy in treatment-naive patients with type 2 diabetes. Curr Med Res Opin. 2009;25(10):2401-2411.

26. DeFronzo RA, Hissa MN, Garber AJ, et al. The efficacy and safety of saxagliptin when added to metformin therapy in patients with inadequately controlled type 2 diabetes with metformin alone. Diabetes Care. 2009;32(9):1649-1655.

27. Chacra AR, Tan GH, Apanovitch A, Ravichandran S, List J, Chen R. Saxagliptin added to a submaximal dose of sulphonylurea improves glycaemic control compared with uptitration of sulphonylurea in patients with type 2 diabetes: a randomised controlled trial. Int J Clin Pract. 2009;63(9):1395-1406.

28. Hollander P, Li J, Allen E, Chen R; CV181-013 Investigators. Saxagliptin added to a thiazolidinedione improves glycemic control in patients with type 2 diabetes and inadequate control on thiazolidinedione alone. J Clin Endocrinol Metab. 2009;94(12):4810-4819.

29. Barnett AH, Charbonnel B, Donovan M, Fleming D. Effect of saxagliptin as add-on therapy in patients with poorly controlled type 2 diabetes on insulin alone or insulin combined with metformin. Curr Med Res Opin. 2012;28(4):513-523.

30. Amori RE, Lau J, Pittas AG. Efficacy and safety of incretin therapy in type 2 diabetes: systematic review and meta-analysis. JAMA. 2007;298(2):194-206.

31. Karagiannis T, Paschos P, Paletas K, Matthews DR, Tsapas A. Dipeptidyl peptidase-4 inhibitors for treatment of type 2 diabetes mellitus in the clinical setting: systematic review and meta-analysis. $B M J$. 2012;344:e1369.

32. Cook W, Bryzinski B, Slater J, Frederich R, Allen E. Saxagliptin efficacy and safety in patients with type 2 diabetes mellitus and cardiovascular disease history or cardiovascular risk factors: results of a pooled analysis of phase 3 clinical trials. Postgrad Med. 2013;125(3):145-154.

33. Minervini G, Cook W, Allen E. Efficacy and tolerability of saxagliptin in patients with type 2 diabetes mellitus and a history of cardiovascular disease. Diabetes. 2013;62 Supp1 1:A306. 
34. Jadzinsky M, Pfutzner A, Paz-Pacheco E, Xu Z, Allen E, Chen R. Saxagliptin given in combination with metformin as initial therapy improves glycaemic control in patients with type 2 diabetes compared with either monotherapy: a randomized controlled trial. Diabetes Obes Metab. 2009;11(6):611-622.

35. Göke B, Gallwitz B, Eriksson J, Hellqvist A, Gause-Nilsson I. Saxagliptin is non-inferior to glipizide in patients with type 2 diabetes mellitus inadequately controlled on metformin alone: a 52-week randomised controlled trial. Int J Clin Pract. 2010;64(12):1619-1631.

36. Cook W, Bryzinski B, Allen E, Hirshberg B. Saxagliptin (SAXA) efficacy and safety in patients with type 2 diabetes mellitus (T2DM) stratified by cardiovascular (CV) risk factors. Endocr Rev. 2013;34:SUN-849.

37. D'Agostino RB Sr, Vasan RS, Pencina MJ, et al. General cardiovascular risk profile for use in primary care: the Framingham Heart Study. Circulation. 2008;117(6):743-753.

38. Bonora E, Allen E, Bryzinski B, Hirshberg B, Cook W. Saxagliptin reduces $\mathrm{HbA} 1 \mathrm{c}$ and is well tolerated in patients with type 2 diabetes and high Framingham 10-year cardiovascular risk. Diabetes. 2013; 62 Suppl 1:A295.

39. American Diabetes Association. Standards of medical care in diabetes 2014. Diabetes Care. 2014;37 Suppl 1:S14-S80.

40. Grant RW, Meigs JB. Prevalence and treatment of low HDL cholesterol among primary care patients with type 2 diabetes: an unmet challenge for cardiovascular risk reduction. Diabetes Care. 2007;30(3):479-484.

41. Bryzinski B, Allen E, Cook W, Hirshberg B. Saxagliptin efficacy and safety in patients with type 2 diabetes receiving concomitant statin therapy. J Diabetes Complications. July 17, 2014. [Epub ahead of print.]

42. Pan CY, Yang W, Tou C, Gause-Nilsson I, Zhao J. Efficacy and safety of saxagliptin in drug-naive Asian patients with type 2 diabetes mellitus: a randomized controlled trial. Diabetes Metab Res Rev. 2012;28(3):268-275.

43. Kumar KMP, Jain S, Tou C, Schützer KM. Saxagliptin as initial therapy in treatment-naive Indian adults with type 2 diabetes mellitus inadequately controlled with diet and exercise alone: a randomized, double-blind, placebo-controlled, phase IIIb clinical study. Int J Diabetes Dev Ctries. 2014:1-9.

44. Yang W, Pan CY, Tou C, Zhao J, Gause-Nilsson I. Efficacy and safety of saxagliptin added to metformin in Asian people with type 2 diabetes mellitus: a randomized controlled trial. Diabetes Res Clin Pract. 2011;94(2):217-224.

45. Hermans MP, Delibasi T, Farmer I, et al. Effects of saxagliptin added to sub-maximal doses of metformin compared with uptitration of metformin in type 2 diabetes: the PROMPT study. Curr Med Res Opin. 2012;28(10):1635-1645.

46. Nowicki M, Rychlik I, Haller H, Warren L, Suchower L, Gause-Nilsson I. Saxagliptin improves glycaemic control and is well tolerated in patients with type 2 diabetes mellitus and renal impairment. Diabetes Obes Metab. 2011;13(6):523-532.

47. Nowicki M, Rychlik I, Haller H, et al. Long-term treatment with the dipeptidyl peptidase-4 inhibitor saxagliptin in patients with type 2 diabetes mellitus and renal impairment: a randomised controlled 52-week efficacy and safety study. Int J Clin Pract. 2011;65(12): $1230-1239$

48. Rosenstock J, Sankoh S, List JF. Glucose-lowering activity of the dipeptidyl peptidase-4 inhibitor saxagliptin in drug-naive patients with type 2 diabetes. Diabetes Obes Metab. 2008;10(5):376-386.

49. Henry RR, Smith SR, Schwartz SL, et al. Effects of saxagliptin on betacell stimulation and insulin secretion in patients with type 2 diabetes. Diabetes Obes Metab. 2011;13(9):850-858.

50. Scheen AJ, Charpentier G, Ostgren CJ, Hellqvist A, Gause-Nilsson I. Efficacy and safety of saxagliptin in combination with metformin compared with sitagliptin in combination with metformin in adult patients with type 2 diabetes mellitus. Diabetes Metab Res Rev. 2010;26(7): $540-549$.
51. Stenlof K, Raz I, Neutel J, Ravichandran S, Berglind N, Chen R. Saxagliptin and metformin XR combination therapy provides glycemic control over 24 hours in patients with T2DM inadequately controlled with metformin. Curr Med Res Opin. 2010;26(10): 2355-2363.

52. White JL, Buchanan P, Li J, Frederich R. A randomized controlled trial of the efficacy and safety of twice-daily saxagliptin plus metformin combination therapy in patients with type 2 diabetes and inadequate glycemic control on metformin monotherapy. BMC Endocr Disord. 2014;14(1): 17 .

53. Neutel JM, Zhao C, Karyekar CS. Adding saxagliptin to metformin extended release (XR) or uptitration of metformin XR: efficacy on daily glucose measures. Diabetes Ther. 2013;4(2):269-283.

54. Fonseca V, Zhu T, Karyekar C, Hirshberg B. Adding saxagliptin to extended-release metformin vs. uptitrating metformin dosage. Diabetes Obes Metab. 2012;14(4):365-371.

55. Tzoulaki I, Molokhia M, Curcin V, et al. Risk of cardiovascular disease and all cause mortality among patients with type 2 diabetes prescribed oral antidiabetes drugs: retrospective cohort study using UK general practice research database. BMJ. 2009;339:b4731.

56. Ryden L, Grant PJ, Anker SD, et al. ESC guidelines on diabetes, prediabetes, and cardiovascular diseases developed in collaboration with the EASD: the Task Force on Diabetes, Pre-diabetes, and Cardiovascular Diseases of the European Society of Cardiology (ESC) and developed in collaboration with the European Association for the Study of Diabetes (EASD). Eur Heart J. 2013;34(39):3035-3087.

57. Engel SS, Round E, Golm GT, Kaufman KD, Goldstein BJ. Safety and tolerability of sitagliptin in type 2 diabetes: pooled analysis of 25 clinical studies. Diabetes Ther. 2013;4(1):119-145.

58. Ligueros-Saylan M, Foley JE, Schweizer A, Couturier A, Kothny W. An assessment of adverse effects of vildagliptin versus comparators on the liver, the pancreas, the immune system, the skin and in patients with impaired renal function from a large pooled database of phase II and III clinical trials. Diabetes Obes Metab. 2010;12(6): 495-509.

59. Schernthaner G, Barnett AH, Emser A, et al. Safety and tolerability of linagliptin: a pooled analysis of data from randomized controlled trials in 3572 patients with type 2 diabetes mellitus. Diabetes Obes Metab. 2012;14(5):470-478.

60. Williams-Herman D, Engel SS, Round E, et al. Safety and tolerability of sitagliptin in clinical studies: a pooled analysis of data from 10,246 patients with type 2 diabetes. BMC Endocr Disord. 2010;10:7.

61. Monami M, Ahren B, Dicembrini I, Mannucci E. Dipeptidyl peptidase-4 inhibitors and cardiovascular risk: a meta-analysis of randomized clinical trials. Diabetes Obes Metab. 2013;15(2):112-120.

62. Hirshberg B, Parker A, Edelberg H, Donovan M, Iqbal N. Safety of saxagliptin: events of special interest in 9156 patients with type 2 diabetes mellitus. Diabetes Metab Res Rev. 2014;30(7): $556-569$.

63. Iqbal N, Parker A, Frederich R, Donovan M, Hirshberg B. Assessment of the cardiovascular safety of saxagliptin in patients with type 2 diabetes mellitus: pooled analysis of 20 clinical trials. Cardiovasc Diabetol. 2014; $13: 33$

64. Hirshberg B, Raz I. Impact of the US Food and Drug Administration cardiovascular assessment requirements on the development of novel antidiabetes drugs. Diabetes Care. 2011;34 Suppl 2:S101-S106.

65. Scirica BM, Bhatt DL, Braunwald E, et al. Saxagliptin and cardiovascular outcomes in patients with type 2 diabetes mellitus. $N$ Engl J Med. 2013;369(14):1317-1326.

66. White WB, Cannon CP, Heller SR, et al. Alogliptin after acute coronary syndrome in patients with type 2 diabetes. $N$ Engl $J$ Med. 2013;369(14):1327-1335.

67. White WB. Cardiovascular outcomes with alogliptin in patients with type 2 diabetes mellitus and recent acute coronary syndromes. Presented at the European Association for the Study of Diabetes annual meeting, September 23-27, 2013, Barcelona, Spain. 
68. Fadini GP, Boscaro E, Albiero M, et al. The oral dipeptidyl peptidase-4 inhibitor sitagliptin increases circulating endothelial progenitor cells in patients with type 2 diabetes: possible role of stromal-derived factor- $1 \alpha$. Diabetes Care. 2010;33(7):1607-1609.

69. Matsubara J, Sugiyama S, Akiyama E, et al. Dipeptidyl peptidase-4 inhibitor, sitagliptin, improves endothelial dysfunction in association with its anti-inflammatory effects in patients with coronary artery disease and uncontrolled diabetes. Circ J. 2013;77(5):1337-1344.
70. van Poppel PC, Netea MG, Smits P, Tack CJ. Vildagliptin improves endothelium-dependent vasodilatation in type 2 diabetes. Diabetes Care. 2011;34(9):2072-2077.

71. Monami M, Lamanna C, Desideri CM, Mannucci E. DPP-4 inhibitors and lipids: systematic review and meta-analysis. Adv Ther. 2012;29(1):14-25.

\section{Publish your work in this journal}

Vascular Health and Risk Management is an international, peerreviewed journal of therapeutics and risk management, focusing on concise rapid reporting of clinical studies on the processes involved in the maintenance of vascular health; the monitoring, prevention and treatment of vascular disease and its sequelae; and the involvement of metabolic disorders, particularly diabetes. This journal is indexed on PubMed Central and MedLine. The manuscript management system is completely online and includes a very quick and fair peer-review system, which is all easy to use. Visit http://www.dovepress.com/ testimonials.php to read real quotes from published authors.

Submit your manuscript here: http://www.dovepress.com/vascular-health-and-risk-management-journal 